Gi rask respons på artikler gjennom artikkelens kommentarfelt på tidsskriftet.no. Respons som er postet innen én måned etter at artikkelen er publisert, vurderes for publisering som Brev til redaktøren i papirutgaven.

Redaksjonen forbeholder seg retten til å foreta redaksjonelle endringer.

Forfattere av vitenskapelige artikler har tilsvarsrett, jf. Vancouver-gruppens regler.

\section{Redusert seleksjonsskjevhet}

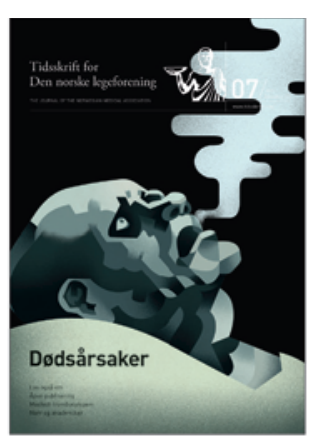

I Tidsskriftet nr. 7/2013 var det en interessant leder om utviklingen i vitenskapelig publisering (1). Én fordel med åpne publiseringsprosesser som ikke er nevnt $i$ lederen, er at de vil redusere risikoen for seleksjonsskjevhet. Fjerner man fagfeller og reduserer redaktørers innflytelse, vil det være færre med forhåndsantakelser om «korrekte» funn.

Jeg kjenner ikke medisinfeltet, men innen økonomi er det i en metametaanalyse av 65 forskningstemaer påvist at seleksjonsskjevhet er utbredt (2). Dette vil fremdeles oppstå med åpne publiseringsprosesser, men det vil nok likevel ikke være et like sterkt behov for avanserte metaregresjonsteknikker for å korrigere for det. Stanley og medarbeideres forslag om å ta et gjennomsnitt av de $10 \%$ mest presise estimatene er en enkel regel alle kan benytte for å avgjøre hva forskningen har funnet (3).

Flere har påpekt farene ved falskt positive funn og behovet for å korrigere for tilfeldigheter (4). Innen enkelte forskningsfelter kan negative funn være teoretisk umulige eller utenkelige, og i slike studier vil positive funn aldri bli oppveid av negative funn, og dermed vil seleksjonsskjevhet alltid være til stede (fordi ekstreme positive funn trekker i gjennomsnittet), også med en åpen publiseringsprosess.

Metaanalysen har derfor ingen usikker fremtid med åpne publiseringsprosesser. Snarere tvert imot: Det vil bli et større datatilfang og dermed flere observasjoner man vil kunne ha som utgangspunkt for metaanalysene.

\section{Stian Skår Ludvigsen}

stian.ludvigsen@hfk.no

Stian Skår Ludvigsen (f. 1976) er ph.d. i statsvitenskap og spesialrådgiver for analyse, utgreiing og dokumentasjon i regionalavdelingen i Hordaland fylkeskommune. Han er medlem av Meta-Analysis for Economics Research Network.

Ingen oppgitte interessekonflikter.

\section{Litteratur}

1. Bjerkestrand S. Åpen kunnskap. Tidsskr Nor Legeforen 2013; 133: 729.

2. Doucouliagos H, Stanley TD. Theory competition and selectivity: are all economic facts greatly exaggerated? Social working paper. Deakin University Australia, 2008. www.deakin.edu.au/buslaw/aef/workingpapers/papers/ 2008_06eco.pdf (10.5.2013).

3. Stanley TD, Jarell SB, Doucouliagos H. Could it be better to discard $90 \%$ of the data? A statistical paradox. Am Stat 2010; 64: 70-7.

4. Bennett C, Baird A, Miller MB et al. Neural correlates of interspecies taking in post-mortem Atlantic salmon: an argument for multiple comparisons correction. http://prefrontal.org/files/posters/Bennett-Salmon-2009.pdf (10.5.2013).

Dette er en redigert versjon av et innlegg publisert som rask respons på nett 9.4. 2013. http://tidsskriftet.no/article/2990497/

\section{Betydningen av tidlig og god intervensjon}

I Tidsskriftet nr. 7/2013 (1, 2) omtales doktoravhandlingen til Carolien Konijnenberg. Den handler om svært sårbare barn eksponert for LAR-medikamenter i svangerskapet. Noen opiateksponerte barn blir født uten påfallende abstinenser, andre kan ha meget store problemer $(3,4)$. Mange er også blitt utsatt for nikotin, psykofarmaka, benzodiazepiner og stress.

Barn med denne «erfaringsbakgrunnen» blir født med «nervene utenpå kroppen». De er ekstremt følsomme for alle former for stimuli - lyd, lys og berøring - og blir lett overstimulert, selv av stimuli i beskjedne og «naturlige» doser (4). De har store problemer med regulering av spising, respirasjon, temperatur og søvn - et abstinent barn kan gå fra søvn til hylskriking på få sekunder. Døgnrytmen er ofte preget av korte soveøkter med hyppige oppvåkninger og mye uro. Derfor trenger de meget bevisst skjerming og sensitiv tilrettelegging.

Barnet kan behøve reiving (pakkes stramt i teppe) for ikke å bli forstyrret av signaler fra sin egen kropp. Normal stimulering, som det å ta på og snakke til barnet, må holdes på et minimum (4). Barna med de kraftigste abstinensene vil også være i behov av abstinensmedisinering med morfin. Graden av abstinenser blir målt med Neonatal Abstinence Score (NAS).

Noen av disse barna vil vokse opp med sine foreldre, andre vil bli plassert i fosterhjem. Uavhengig av det vil de være helt avhengige av spesialkompetent hjelp rett etter fødselen og den første tiden etterpå. Dette for å vurdere behovet for abstinensmedisinering - det kreves et trent øye for å forstå og tolke til dels subtile signaler på stress fra barnet riktig. Videre kreves spesialkompetanse for å vurdere de biologiske foreldrenes omsorgsevne for barnet, både på kort og på lang sikt.

Et slikt tilbud finnes i dag ved Aline barnevernsenter i Oslo. Hit kommer barna ofte kun få dager/uker gamle, rett fra sykehuset, til en sømløs tiltakskjede med svært spisskompetent og tverrfaglig personell.

Denne doktoravhandlingen viser at barn eksponert for LARopiater under svangerskapet har økte problemer både kognitivt, motorisk og atferdsmessig sammenlignet med kontrollbarn (1). Alt dette gir en sårbarhet for skjevutvikling som kan vise seg både $i$ barnehage og skole og i jobbsammenheng. Avhandlingen understreker betydningen av både tidlig og langvarig intervensjon. Disse barna kan bli hjulpet til et godt og normalt liv, men de trenger god utviklingsstøtte for å oppnå et best mulig resultat. Hjelpen må starte så raskt som mulig og være av god kvalitet.

I disse dager vurderer Oslo kommune om dagens tilbud ved Aline barnevernsenter skal splittes opp. For fremtiden til disse sårbare små håper jeg at dette stoppes. Jeg ber myndighetene i hovedstaden om at dagens gode og nødvendige tilbud til disse barna får bestå.

\section{Krister Moström}

mostromuhals@hotmail.com

Krister Moström (f. 1976) er medisinsk ansvarlig lege ved Aline barnevernsenter.

Ingen oppgitte interessekonflikter.

\section{Litteratur}

1. Konijnenberg C. A prospective study of the cognitive development of children prenatally exposed to opioid maintenance treatment (OMT). Doktoravhandling. Oslo: Universitetet i Oslo, 2013

2. Bergset T. Sårbare barn. Tidsskr Nor Legeforen 2013; 133: 740

3. Moe V, Slinning K, Hansen MB. Håndbok i sped-og småbarns psykiske helse. Oslo: Gyldendal, 2010.

4. Nugent JK, Keefer $\mathrm{CH}$, Minear S et al. Understanding newborn behavior \& early relationships: the newborn behavioral observations (NBO) system handbook. Baltimore, MD: Paul H. Brooks, 2007.

Dette er en redigert versjon av et innlegg publisert som rask respons på nett 22.4.2013. http://tidsskriftet.no/article/2991137/ 